\title{
Bursa florasının doğa turizmi potansiyeli
}

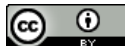

\section{Nature tourism potential of the flora of Bursa}

\author{
Kamil ERKEN $^{1}$ (D), Gül ATANUR ${ }^{1}$ iD, Anıl AKIN TANRIÖVER ${ }^{2}$ iD \\ ${ }^{1}$ Bursa Teknik Üniversitesi Orman Fakültesi Peyzaj Mimarlığı Bölümü, Bursa Türkiye \\ ${ }^{2}$ Bursa Teknik Üniversitesi Mimarlık ve Tasarım Fakültesi, Şehir ve Bölge Planlama Bölümü, Bursa Türkiye
}

Eser Bilgisi/Article Info
Araştırma makalesi / Research article
DOI: $10.17474 /$ artvinofd.487365
Sorumlu yazar/Corresponding author
Kamil ERKEN
e-mail: kamil.erken@btu.edu.tr
Geliş tarihi / Received
25.11.2018
Düzeltme tarihi / Received in revised form
04.04.2019
Elektronik erişim / Online available
12.04.2019
Anahtar kelimeler:
Bursa
Flora
Bitkiler
Doğa turizmi
Keywords:
Bursa
Flora
Plants
Nature tourism

\begin{abstract}
Özet
Kent yaşamının, trafik, stres, gürültü ve yapılı çevre içinde sıkışmış rutin yaşam tarzı insanları doğaya ve doğal yaşama doğru yönlendirmektedir. Koruyarak doğayı yaşama, keşfetme, farklı kültürleri anlama, yereldeki kaynakları ve getirisini yerel halkla paylaşma, yerel ve doğal kaynakların sürdürülebilir kullanımı ile mümkündür. Bu faaliyetler doğal kaynakların ekonomiye kazandırılması, kırsal kesimde yaşayanların hayat standartlarının yükseltilmesi, turizm alanlarının, faaliyetlerinin ve gelirlerinin çeşitlendirilmesi ve artırılması konularıyla da örtüşen ortak hedefler içermektedir. Doğa turizmi faaliyetlerinin çoğunluğu flora tabanlı faaliyetlerdir. Marmara Bölgesi ve özellikle Bursa, biyoçeşitlilik ve yoğun florası ile ülkemizin doğa turizmi açısından Karadeniz Bölgesi'nden sonra en önemli alanlarıdır. Coğrafi konumu, sahip olduğu zengin ve yoğun orman alanları ve Uludağ Milli Parkı, Bursa'yı botanik turizmi, foto safari, doğa yürüyüşü, doğa gözlemciliği, tıbbi bitkilere bağı sağlık turizmi, macera oyunları turizmi gibi floraya bağlı doğa turizmi alanlarında merkez olabilecek bir konuma taşımaktadır. Bu çalışmada Bursa'da ekoturizmin çeşitlendirilmesi ve canlandırılması için floraya bağlı doğa turizmi faaliyetleri açısından Bursa'nın sahip olduğu potansiyel ortaya konulmuş, SWOT analizi ile değerlendirilmiş ve öneriler oluşturulmuştur.
\end{abstract}

\begin{abstract}
The routine lifestyle of the urban environment that are stuck in the traffic, stress, noise and built environment directs people towards the nature and natural life. Nesting life with nature and recreation in the natural environment has become the dream of everyone living in the city. The efforts of the living nature by protecting, discovering, understanding different cultures, to share local resources and returns with local people, sustainable use of local and natural resources has brought up nature tourism activities. These activities have included common objectives with the general social goals like acquisition of natural resources into the economy, raising living standards of rural people, tourism areas, activities and revenues diversification and boosting. The majority of nature tourism activities are related with the natural flora. Marmara Region and especially Bursa, with its biodiversity and intensive flora, are the most important areas of our country after the Black Sea Region in terms of nature tourism. Botanical tourism, photo safari, hiking, nature watching, health tourism related to medical plants, adventure games tourism is flora connected nature tourism activities. Geographical location, rich and dense forest areas and the Uludag National Park put Bursa in a position to be the center of nature tourism. In this study, the potential of Bursa in terms of nature tourism related to flora has revealed.
\end{abstract}

\section{Giriş}

Turizm denilince öncelikle akla gelen deniz, kum, güneş algısı günümüzde değişmiş, doğal, tarihi, kültürel, sosyal ve estetik değerlere bağlı birçok turizm faaliyet alanı gelişmiştir. Klasik tatil anlayışından eğitim, çevre, keşif, macera-eğlence alanlarına kayılması, turistlerin ve turizmcilerin doğaya ve doğal kaynaklara yönelmelerini sağlamıştır (Düzgüneş ve Demirel 2013). Turizm anlayışındaki değişimlere paralel olarak ortaya çıkan yeni talepler, turizm potansiyeli yüksek olan ülkelerin turizm faaliyetlerinde çeşitlendirmeye gitmelerini zorunlu hale getirmiştir. Bunun üzerine bütün dünyada bilinen klasik turizm faaliyetlerine ek olarak doğa eksenli alternatif turizm alanlarına yönelme başlamıştır (Tuncer ve Çavuş 2017).

Toplumlardaki bilinçlenme, kaynakların korunması ve bu kaynaklardan sürekli faydalanmayı temin etmek ve tüketimini engellemek için sürdürülebilir turizm ve ekoturizm kavramları ortaya çıkmıştır (Cincioğlu 2016). Ekoturizm, turizm faaliyetleri içerisinde en hızlı gelişen turizm dalı haline gelmiştir (Anonim 2012). 
Ekoturizm kavram olarak, doğaya ve faaliyet alanına zarar vermeden, yerel halkın menfaatlerini de gözeterek, sürdürülebilir ve çevreye duyarlı kullanım ilkeleri çerçevesinde, doğal alanlarda gerçekleştirilen turizm faaliyetleridir (Erdoğan 2003; Veen and Song 2014). Kültür ve Turizm Bakanlı̆̆ı, ekoturizmi; yayla turizmi, kuş gözleme turizmi, foto safari, çiftlik turizmi, akarsu sporları, botanik (bitki inceleme) turizmi, bisiklet turları, atlı doğa yürüyüşü, kamp-karavan turizmi, mağara turizmi, dağ turizmi ve doğa yürüyüşü gibi başlıklar altında değerlendirmektedir (Kaypak 2010). Ekoturizmde sürdürülebilirlik ve çevreye duyarlılık, kaynakların korunması, yerel halkın da bu faaliyetlerin içine çekilmesi ve yerel düzeyde insanların yaşamlarını destekleyerek kalkınmaya yardımcı olması temel esastır. Ekoturizmin ekolojik kökenli olması, ekoturizm faaliyetlerinin doğa, kültür, biyolojik çeşitlilik üzerine kurgulanmasını sağlamıştır (Kaypak 2012).

Uluslararası Ekoturizm Topluluğu’na göre Doğa Turizmi: "Doğal alanları tecrübe etmeye yönelik olan ekolojik olarak sürdürülebilir turizm"dir. Doğa turizmi, doğa ve doğayla ilgili olguların, bu alanları ziyaret etmek için temel güdülenme olduğu, doğal alanlara yapılan seyahattir. Doğa turizmi, doğal kaynakların uygun bir şekilde, zarar görmeden kullanımını amaçlarken, ziyaretçilerin bu şekilde eğlenme, dinlenme ve yenilenmelerine olanak sağlar (Yılmaz ve Karahan 2003; Anonim 2015b). Doğa turizmi her mevsim yapılabilecek faaliyetleri kapsamaktadır. Bu yönüyle doğal ve yerel kaynaklardan tüm yıl faydalanma için ideal kullanım doğa turizmidir (Oktay ve ark. 2016; Ankaya ve ark. 2018).

Ülkemiz bu değerler açısından oldukça zengin kaynaklara ve olanaklara sahiptir. Coğrafi yapısı, iklimi, ekolojisi, bitki örtüsü, Anadolu'nun binyıllara dayanan tarihi, toplumumuzun köklü ve çeşitlilik içeren kültürü bizim yeni turizm faaliyetleri açısından da vazgeçilmez ülkeler arasına girmemizi sağlamıştır. Sahip olduğumuz yeni ve alternatif turizm kaynakları ülkemize her geçen gün daha fazla turistin ziyareti anlamına gelmektedir (Kaypak 2012; Ankaya ve ark. 2018). Turizm tarihsel, kültürel ve doğal alanları da kapsayan özel alanlarda gerçekleşmektedir (Atanur ve Özer 2008). Türkiye bu olanaklar açısından dünyanın önde gelen ülkelerinden birisidir.
Son yıllarda insanların doğaya, doğal bitkilere ve biyolojik çeşitliliğe olan ilgisi ekoturizm ya da doğa turizminin alt çeşitlerinden biri olan flora turizmini ya da yakın anlamda kullanılan botanik turizmini gündeme getirmiştir. Flora turizmi, floranın doğaya sunduğu rahatlatıcı etkisi ile beraber, doğayı, bitkileri ve doğal ürünleri tanımaya, keşfetmeye incelemeye hatta onların sunduğu şifa olanaklarından faydalanmaya yönelik turizm faaliyetidir. Türkiye gibi bitkisel biyoçeşitliliği yüksek nadir ve endemik bitki sayısı fazla olan ülkeler için umut vadeden bir turizm faaliyet alanı olarak görülmektedir (Külekçi ve Bulut 2016).

Türkiye dağları, ormanları, yaylaları, kıyıları, gölleri, akarsuları, florası ve faunası gibi tabii varlıkları ile doğa turizmi için avantajı ülkeler arasında yer almaktadır. Marmara Bölgesi ve Bursa bu doğal kaynakların çeşitlilik ve yoğunluk olarak en fazla olduğu coğrafi alanları kapsamaktadır.

Bu çalışmada; Ülkemizde mevcut doğal kaynakların sürdürülebilir kullanımı sağlanarak ekonomik değerlere dönüştürülmesi, Bursa'da ekoturizmin çeşitlendirilmesi ve canlandırılması amacıyla, Bursa ili sınırlarında bulunan floraya bağlı doğa turizmi için uygun alan ve kaynaklar ile bu kaynaklara bağı olarak yapılabilecek doğa turizmi faaliyetleri ortaya konulmuştur.

\section{MATERYAL ve YÖNTEM}

\section{Materyal}

Bu çalışmanın materyalini Marmara Bölgesi'nde yer alan Bursa'nın florası, ve floraya bağlı doğal kaynaklar (doğal peyzaj değerleri) oluşturmaktadır. Çalışma alanının konumu ve sınırları Şekil 1'de verilmiştir.

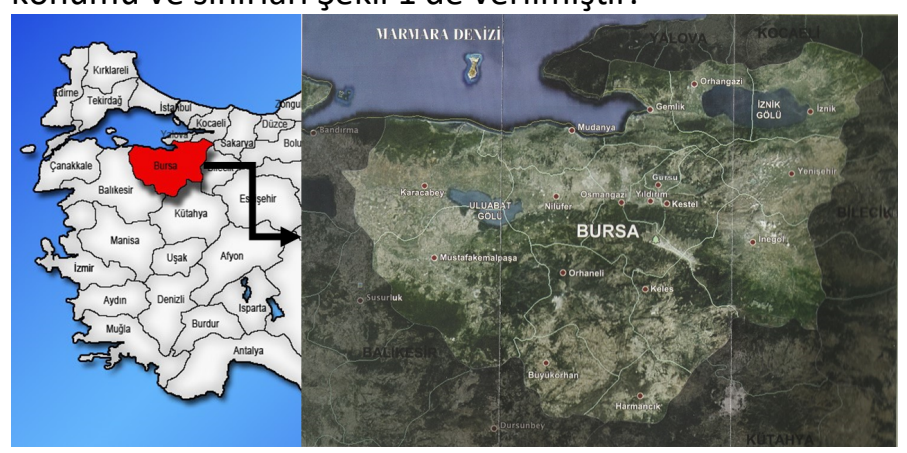

Şekil 1. Çalışma alanı sınırları ve konumu. (harita http://www.bursakulturturizm.gov.tr'den alınmıştır.) 
Bursa'da Akdeniz ve Karadeniz bitki örtülerini de içeren geçiş kuşağı bitki örtüsü hakimdir. Dağların kuzeye bakan yamaçları başta kestane ve ıhlamur olmak üzere geniş yapraklı ormanlar ile kaplıdır (Şahinbaş 2016). Topografyası ve farklı bitki kuşakları nedeniyle çok zengin çeşitliliğe ve yüksek endemizm oranına sahiptir. Bu potansiyelde doğa turizmi açısından değerlendirilmesi gereken bir kaynaktır.

Anadolu yarımadasının kuzeybatı kısmında Marmara bölgesinde yer alan Uludağ ülkemizin en yüksek yeryüzü şekillerinden biridir. Platolar, göller, kalkerli dik kayalık alanlar, tüm yıl kalan kar çukurları, tüm yıl bol akan su kaynakları Uludağ'ın zenginlikleridir. Dağın alt kısımlarından zirveye doğru değişen, yüksek rakım, coğrafi şekiller ve iklim özellikleri Uludağ'a oldukça zengin bir biyolojik çeşitlilik kazandırmıştır. Bitkisel çeşitlilik açısından ülkemizde belirlenen 122 Önemli Bitki Alanı'ndan biri ve en önemlilerindendir (Özhatay ve ark. 2005).

Şubat-mart aylarında alt rakımlardan başlayan çiçeklenme, zirveye yakın kuşakta yaz sonunda ağustos ayına kadar devam etmektedir. 1998 yılından beri 12762 hektarlık alanı Milli Park sınırları içinde yer almaktadır (Güleryüz 2000; Şahinbaş 2016). Botanikçi Meyer'e göre "Uludağ sadece bir dağ değil aynı zamanda bir laboratuvardır" (Şahinbaş 2016). Dolayısıyla bitki örtüsü, yaban hayatı ve manzara bütünlüğüne sahip alanları, araştırmalar ve eğitim çalışmaları için bir laboratuvar olduğu gibi aynı zamanda sürdürülebilir turizm uygulamaları ile yerel, bölgesel ve ulusal düzeyde ekonomiye katkı sağlayan bir doğal kaynaklar bütünüdür.

\section{Yöntem}

Çalışmanın yöntemi aşağıda sıralanan süreç çerçevesinde geliştirilmiştir.

- 2006-2014 yıllarında farklı projeler kapsamında Türkiye ve Bursa florası ile ilgili çalışmalar yürütülmüştür (Erken ve ark. 2009; Erken ve Özzambak 2011; Kaya ve ark. 2014). 2014-2018 yıllarında başta endemik ve nadir bitkiler olmak üzere, alanla ve florası ile ilgili projesiz faaliyetler devam etmiştir.
- Yapılan arazi çalışmalarında elde edilen flora ile ilgili veriler, literatür çalışmaları ile sentezlenerek floraya bağı̆ peyzaj kaynakları belirlenmiştir.

- Elde edilen veriler SWOT (GZFT) (Strengths, Weaknesses, Opportunities, Threats -Güçlü yönler, Zayıf yönler, Fırsatlar, Tehditler) analizi ile değerlendirilmiştir.

- Flora kökenli doğal turizm faaliyetleri değerlendirilerek Bursa florasının potansiyel doğa turizmi çeşitleri ortaya konulmuştur.

- Ortaya konulan faaliyetlerden 2013 yılında hazırlanan "Bursa Doğa Turizmi Eylem Planı 2013-2017", "Bursa İli Tabiat Turizmi Uygulama Eylem Planı 2016-2019" ve 2016 yılında hazırlanan "Uludağ 4 Mevsim Sürdürülebilir Turizm Planı"nda yer verilmiş olan faaliyetlere ilave olarak planlanabilecek potansiyel doğa turizmi faaliyetleri listelenerek incelenmiştir (Anonim 2015; Anonim 2016).

Yapılan arazi çalışmalarında dikkat çeken kullanımlar, eksiklikler, potansiyel kaynaklar ve turizm faaliyetleri intiyaçları doğrultusunda öneriler oluşturulmuştur.

\section{BULGULAR}

\section{Bursa'nın Turizme Uygun Alanları ve Doğa Turizmi Seçenekleri}

Bursa'nın doğa turizmi faaliyetleri için kullanılabilecek flora kökenli doğal kaynakları şunlardır;

- Uludağ Milli Parkı,

- Sadağı kanyonu tabiat parkı,

- Suuçtu Tabiat Parkı,

- Yaylalar,

- Doğal piknik alanları,

- Manzara noktaları,

- Ormanlık alanlar,

- Kestane ihlamur ormanları,

- Kocaçay Deltası (Karacabey longozu),

- Floradaki meyvesi yenebilen doğal türler,

- Florada sebze olarak tüketilen türler,

- Florada tıbbi ve aromatik bitki olarak tüketilen türler,

- Floradaki endemik ve nadir türler,

- Anıt ağaçlar. 
Doğa turizmi; doğal kaynakların sürdürülebilir kullanımını amaçladığına göre, Bursa florasının sahip olduğu ve yukarıda listelenen kaynaklara bağlı olarak yapılabilecek doğa turizmi faaliyetleri de şu şekilde sıralanabilir.

- Kampçılık ve yayla turizmi

- Piknikçilik

- Doğa yürüyüşü

- Doğa ve bitki fotoğrafçılığı

- Botanik turları

- Doğa ve macera oyunları

- Yenilebilir, içilebilir ve şifalı bitki (Etnobotanik) turları

- Anıt ağaç turları

- Longoz ormanı turları

Bursa'da yapılabilecek flora temelli doğa turizmi türleri şunlardır:

Kampçılık ve yayla turizmi

Kampçılık, piknikçilik ve yayla turizmi doğa turizminin çok eskiden beri bilinen ve en çok yapılan dallarındandır. Özellikle Türk kültüründe yüzyıllardan beri bilinen turizm anlamının dışında hayat tarzı olarak benimsenen faaliyetlerdir. Günümüzde ise kent nüfuslarındaki artışa bağlı olarak artan doğaya özlem duygusu insanları doğaya yönlendirmektedir. Serin iklime sahip doğal alanlar ve yaylalar şehir hayatının olumsuzluklarının tedavisinde kullanılan birer terapi merkezi haline gelmiştir. Yaylalarda ve kamp alanlarında doğa turizmi amaçlı konaklayan yerli ve yabancı turistler için, doğa yürüyüşleri, piknikçilik, doğal yaşam gözlemciliği, sezona bağlı olarak kar yürüyüşü gibi faaliyetler ek planlama, malzeme ve yatırıma gerek duymadan gerçekleştirilebilecek doğa turizmi faaliyetleridir. Ek imkanlar sağlandığı takdirde, doğa ve bitki fotoğrafçılığı, atlı doğa yürüyüşü, dağcılık ve tırmanma, dağ bisikleti turları, bu konuda yetkin rehber bulunması durumunda, botanik turları, kuş, kelebek gözlemciliği, yenilebilir doğal meyveli bitki, tıbbi amaçlı bitki (şifalı bitki) gözlem inceleme ve toplama faaliyetleri yakın mesafelerde ve birbirlerine bağlı olarak planlanabilecek doğa turizmi faaliyetleridir.

\section{Piknikçilik}

Bugün Uludağ için kampçılıkla birlikte en yoğun gerçekleşen faaliyettir. Fakat sadece belli bölgede ve sıkışık bir alanda gerçekleştirilmektedir. Günübirlik ve yöre halkının bir faaliyeti olduğundan tek başına düşünüldüğünde ulusal ve uluslararası bir turizm faaliyeti olarak görülen bir faaliyet değildir. Fakat kampçılık ve yayla turizmi, doğa yürüyüşleri, doğa fotoğrafçılı̆ı̆, botanik turları gibi turizm faaliyetleri ile birlikte bağlantılı ve birbirini tamamlayacak şekilde planlandığında ulusal ve uluslararası turizm faaliyetlerinin bir parçası haline getirilebilecek bir konudur.

\section{Doğa yürüyüşü}

Her yaştan insanın kendi performansı ölçüsünde yapabileceği bir rekreasyon faaliyetidir. Zorluk derecesi ve mesafesi farklı parkurlar çok farklı eylemlerle desteklenerek zengin içeriklere sahip doğa yürüyüşü güzergahları planlanabilir. En basit olanı düz bir alanda bitki örtüsünün sunduğu güzellikler içerisinde, istenilen mesafede yapılan yürüyüştür (Gürsoy 2015). Bölgenin, floranın faunanın ve coğrafyanın sağladığı imkanlara göre, doğa yürüyüşü parkurları güzergah üzerindeki diğer faaliyetler ile desteklenerek geniş kapsamlı turizm faaliyetine dönüştürülmesi mümkündür. Bursa bu faaliyetlerden birçoğunu tek güzergahta buluşturabilecek parkur alanlarına sahiptir (Anonim 2012).

Bursa florası içerisindeki doğa yürüyüşü alanları sağlıklı insanlar için macera ve rekreasyonel faaliyet alanı olarak kullanılırken, akciğer rahatsızlıklarında ve psikolojik rahatsızlıklarda terapi alanı olarak da kullanılabilecek imkanlara sahiptir. Bu farklı kullanımlar için farklı zorluklarda ve amaca hizmet edecek uygun güzergahlarda planlanacak doğa yürüyüşü parkurları Bursa için alternatif bir yatırım alanı oluşturabilecek kapasitededir.

\section{Doğa ve bitki fotoğrafçılığı}

Bursa deniz seviyesinden $2543 \mathrm{~m}$ rakıma yükselirken farklı iklime, coğrafi oluşumlara, farklı flora ve faunaya dolayısıyla çeşitliliğe ve ilgi çekici güzelliklere sahip bir ekosistem çeşitliliği gösterir. Mevsime bağlı olarak değişen bitki örtüsü zengin renk skalasına sahip manzaraları yıl boyunca sunar. Deniz, akarsular, göller, sulak alanlar, kuş konaklama alanlarının sayı ve çeşitliliği, 
Bursa'yı diğer illerden üstün kılan endemik bitkiler ve hayvanlar zenginliği doğa ve bitki fotoğrafçıları için fırsat alanlarıdır. Doğa fotoğrafçılı̆ı turizminde ana materyal doğal peyzajın bileşenleri ve özelliklede bitkilerdir. Uludağ 2543 m yüksekliği ile bölgenin en yüksek coğrafi yükseltisidir. Bu yükseltinin sahip olduğu bitki zonları bitki fotoğrafçıları için manzaranın her açısını, rengin her tonunu yakalama olanağı sunmaktadır (Şekil 2 ve Şekil 3).

\section{Botanik turları}

Yapılan çalışmalarda Bursa florasına kayıtlı 113 familya ve 634 cinse ait 1808 takson tespit edilmiştir (Malyer ve ark. 2016). Bursa'nın en yoğun bitkisel biyoçeşitliliğe sahip kısmı Uludağ'dır. 1300 civarındaki farklı türden oluşan bitki çeşitliliği, 30 tanesi sadece Uludağ'a, 107 tanesi Türkiye'ye has, küresel ölçekte nesli tehlike altında olan 3 ve Avrupa ölçeğinde nesli tehlike altında olan 54 olmak üzere 169 endemik tür (Daşkın ve Kaynak 2010; Daşkın ve Kaynak 2010b; Malyer ve ark. 2016) Uludağ'ı bir bitki laboratuvarı haline getirmiştir. Uludağ'da endemizm oranı \%12,9 düzeyindedir. Uludağ göknarı (Abies nordmanniana subsp. bornmulleriana) da Uludağ'ın endemik bir türüdür. Oran olarak Türkiye ortalamasına göre (\%34) düşük bir oran gibi görünse de bu kadar endemik taksonun sadece Uludağ'da toplanması yoğunluk olarak bir avantajdır. Botanikçiler ve bu konuya meraklı turistler için botanik turları Bursa'nın en iddialı olacağı doğa turizmi faaliyetlerinden biridir. Bursa coğrafyasının 1 metreden 2343 metreye kadarki rakım farkı bitki örtüsüne aynı türde bir aylık bir gelişme dönemi farklılı̆ı imkânı sağlamaktadır. Bu durum çiçeklenme dönemini daha geniş bir sezona yayarak aynı türü farklı rakımlarda daha geniş bir zamanda çiçekli bulma imkânı vermektedir (Şekil 2 ve Şekil 3).

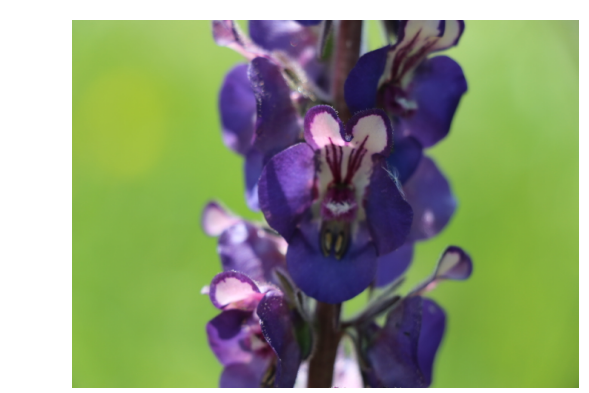

Küresel endemik Verbascum yurtkuranianum GürsuBursa (Fotograf; B. Gönül)

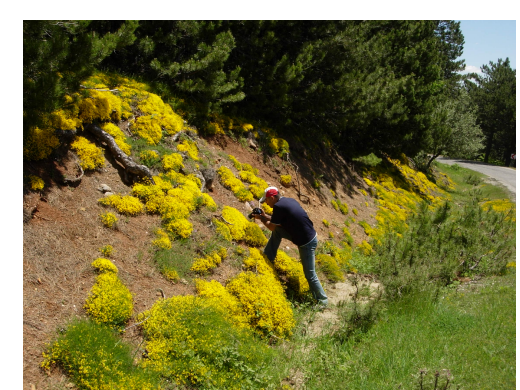

Uludağ doğal bitkilerinden Genista lydia var lidia popülasyonu (Orijinal)

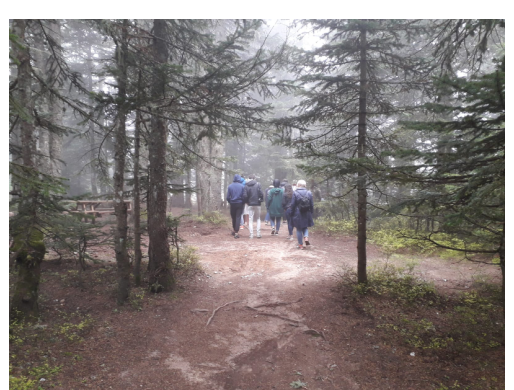

Endemik Uludağ Göknarı (Abies nordmanniana subsp bornmülleriana) ormanında doğa yürüyüşü (Orijinal)

Şekil 2. Bursa florasında bulunan botanik turizmi ve doğa fotoğrafçılığı için cazip bitki örnekleri ve doğa yürüyüşü alanı

\section{Doğa ve macera oyunları}

Kent yaşamının stresi içinde yaşayan insanların psikolojik rahatlama, takım ruhunu geliştirme ve grupların kaynaşması amaçlı olarak yapılmaya başlanan ve çok rağbet gören faaliyetlerdir. Doğal ormanlık alanlarda oynanan bu oyunlar özellikle büyük kentlere yakın bölgelerde yoğun talep görmektedir. İstanbul, Kocaeli, Sakarya Eskişehir gibi büyük ve kalabalık şehirlerin bulunduğu, ulaşım ağlarının odak noktası Güney Marmara bölgesinde yer alan Bursa bu turizm faaliyeti açısından da yüksek potansiyele sahiptir. Macera oyunlarına heyecan katan faktör coğrafi koşullar ve bitki örtüsüdür. Farklı coğrafi zorlukların olduğu orman alanlarında oluşturulacak macera oyunları parkurları yatırım yapılması gereken doğa turizmi faaliyet alanları arasında yer almaktadır.
Yenilebilir, içilebilir ve şifalı bitki (Etnobotanik) turları Bugün tarımda kullandığımız tüm meyve ve sebzelerin orijinleri doğal bitkilerdir. Zaman içerisinde ıslah çalışmaları ile günümüzdeki şekillerini almışlardır. Tüm türlerin küçük meyveli doğal halleri doğada mevcuttur. Ülkemiz tarım ürünlerinin gen merkezlerinden biridir. Floramız meyve ve sebze türleri doğal tipleri açısından zengindir. Bursa florasında doğal olarak bulunan meyve, sebze, baharat olarak tüketilen ve şifa amaçlı kullanılan yabani türlerin bulunduğu bölgelere yapılan doğa turları (etnobotanik turları) insanların ilgisini çekecek doğa turizmi faaliyetleridir. Alternatif tıbbın, doğal ve organik beslenmenin revaçta olduğu günümüzde, yetişmiş rehberler eşliğinde belirlenen güzergâhlara ve belirlenen dönemlerde yapılacak turlar Bursa doğa turizmi için büyük potansiyel içermektedir. 
Kuşburnu (Rosa canina), doğal erik (Prunus spinosa, Prunus domestica), kuş kirazı (Prunus avium), elma (Malus sylvestris), ahlat (Pyrus elaeagnifolia), bögürtlen (Rubus fruticosus), çilek (Fragaria vesca), kestane (Castanea sativa), alıç (Crataegus monogyna), çitlenbik (Celtis australis) muşmula (Mespilus germanica), yaban mersini (Vaccinium myrtillus), dağ çileği (Arbutus unedo), geyik elması (Malus trilobata) doğadan toplanabilecek doğal meyve türlerinden bir kısmıdır. Başta ıhlamur (Tilia spp.), defne (Laurus nobilis), adaçayı (Salvia spp.) ve kekik (Thymus spp.) olmak üzere, kişniş (Coriandrum sativum), sumak (Rhus typhina), nane (Mentha piperita), altınotu (Helichrysum arenarium), kantaron (Hypericum perforatum), aslanpençesi (Allcemilla vulgaris), rezene (Foeniculum vulgare), civanperçemi (Achillea millefolium), devedikeni (Silybum marianum), lavanta (Lavandula pedunculata), papatya (Matricaria chamomilla), öksürükotu (Tussilago farfara), şerbetçiotu (Humulus lupulus), hatmi (Althaea officinalis) ve yüksükotu (Digitalis ferruginea) tıbbi amaçlı toplanan türlere örnektir. Kuzukulağı (Rumex acetosella), deniz börülcesi (Salicornia europea), ebegümeci (Malva sy/vestris), eşek dikeni (Onopordum illyricum), eşek marulu (Sonchus oleraceus), ışgın (Rheum ribes), kuşkonmaz (Asparagus sp.), mantar (Lactarius salmonicolar - Kanlıca mantarı, Chroogomphus rutilus geyik mantarı, Coprinus comatus- kuzu göbeği mantarı vb), çiriş (Eremurus spectabilis), gelincik (Papaver rhoeas), hardalotu (Sinapis arvensis), hindiba (Cichorium intybus), Isırgan (Urtica dioica), semizotu (Portulaca oleracea), turp otu (Raphanus raphanistrum) ve yabani sarımsak (Allium sp.) doğadan toplanan ve sebze olarak tüketilen bazı doğal bitki türleridir (Karamanoğlu ve Öder 1973; Bremness 1999; Karaca ve ark. 2015). Bu türlerden birçoğu Bursa'nın hatta Uludağ'ın birçok noktasında geniş popülasyonlar halinde mevuttur. On beş milyon nüfuslu İstanbul ve iki milyon nüfuslu Bursa'dan bu bitkileri doğal ortamından toplamak isteyen oldukça fazla sayıda insan bulmak mümkündür.

\section{Anıt Ağaç Turları}

Hikâyesi olan yaşlı, heybetli ağaçlar insanların ilgisini çekmektedir. Bunun en iyi örneği de yine Bursa'da mevcuttur. İnkaya Tarihi Çınar'ı Türkiye'nin en çok bilinen ve en fazla turist çeken anıt ağaçlarından biridir. Bursa'da bu çınara benzer yaşlı anıt ağaçlar mevcuttur. Bursa'nın Nilüfer ilçesine bağlı Gölyazı köyünde bulunan Ağlayan Çınar hikâyesiyle, Kestel ilçesine bağıı Dudaklı köyündeki 'Çınarcık' isimli 1200 yaşında olduğu tahmin edilen anıt ağaç yaşıyla ilgi çekecek değerlerdir. Bunların dışında; Kavaklı Çınar, Dua Çınarı, Koğuk Çınar, Ulufeli Çınar, Muradiye Çınarı ve Baba Sultan Çınarı Bursa'nın hikâyesi olan yaşlı anıt ağaçlarıdır (Kaptan 2018).

\section{Longoz ormanı turları}

Longoz ormanı; zemini su altında kalmış ve çok fazla rastlanmayan ender oluşumlardır. Bu alanlarda suya dayanıklı ağaç vejetasyonu ve zeminde su bitkileri ile çok farkı ekosistemler ortaya çıkmakta ve orman canlıları ile suya bağlı yaşayan canlılar bir arada görülmektedir. Karacabey ilçesinin Marmara sahilindeki Yeniköy böyle bir oluşuma sahiptir. Karacabey longoz ormanı ve lagün gölü olarak bilinen bu bölge dişbudak, kızılağaç ve söğüt ormanı, mavi su yüzeyinin üzerinde yer yer yeşil bitkiler ve rengarenk açan su bitkileri ile doğa fotoğrafçıları, kuş gözlemcileri, doğa yürüyüşçüleri ve ruhunu dinlendirmek isteyen turistler için çeşitli olanaklar sunan bir alandır. Kardeleni andıran göl soğanları (Leucojum aestivum), nilüferler (Nymphaea alba) ve longoz ormanının sahil kesiminde bulunan kumullardaki çok geniş ve yoğun lavanta (Lavandula pedunculata subsp. cariensis) popülasyonları da bu bölgenin önemini arttırmaktadır (Anonim 2012; Anonim 2015; Anonim 2016) (SSekil 3). Lavantaların çiçekli döneminde bu kumullar lavanta mavisi rengi ile tüm dikkatleri kendine çekmektedir. Arkadaki sık ormanlarla denizin iç içe geçmiş kesişim noktası konumundaki longoz ormanı doğa turizmi potansiyeli yüksek bir kaynaktır. Lagünün önemli bir türü, nilüfer (Nymphaea alba)'dir. Nilüfer su bitkilerinden estetik özellikleri yüksek olan bir türdür. Karacabey longozu dışında Uluabat gölü de Türkiye'nin en geniş nilüfer popülasyonlarına sahiptir. Gölün kuzeydoğu kıyıları ile Mustafakemalpaşa çayının göle bağlandığı noktalarda oldukça geniş nilüfer popülasyonları bulunmaktadır (Şahinbaş 2016).

\section{Bursa Florasının Doğa Turizmine iliş̦kin Swot Analizi}

Bursa'nın mevcut kaynak değerler açısından güçlü ve zayıf yönleri ile sahip olduğu firsat ve tehditler SWOT analizi yöntemi ile değerlendirilmiştir (Çizelge 1 ). 


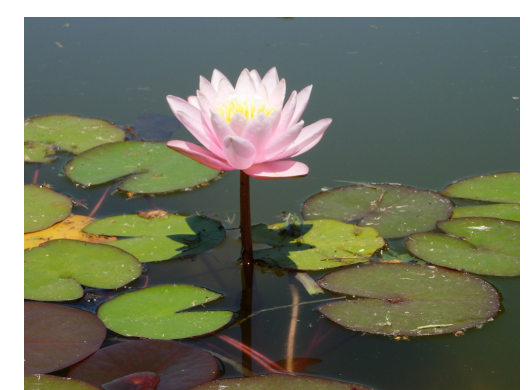

Kocaçay Deltası Sulak Alanı (Longoz ormanı)'nda nilüfer çiçeği (Orijinal)

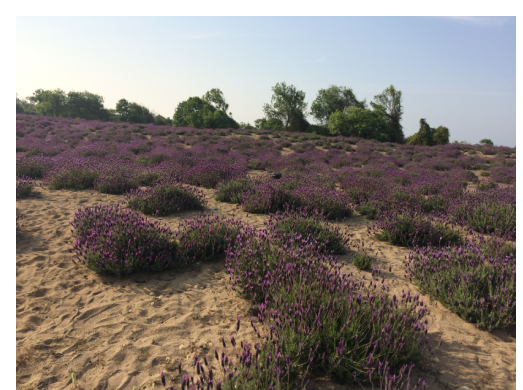

Longozun sahil kısmında kumul alanda lavanta (Lavandula pedunculata subsp. cariensis) popülasyonu (Fotograf; S. Parlak)

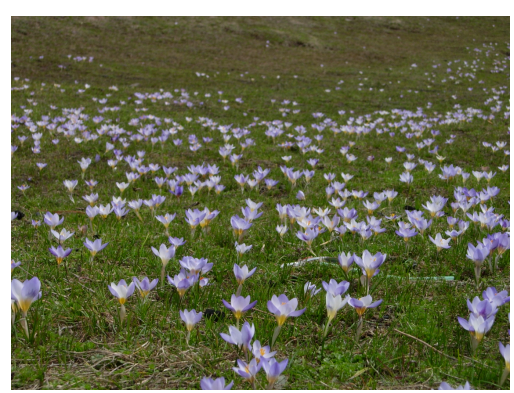

Uludağ yaylada bahar görüntüsü (Orijinal)

Şekil 3. Bursa florasında bulunan botanik turizmi ve doğa fotoğrafçılığı için cazip bitki örnekleri

Çizelge 1. Bursa florası'nın doğa turizmi potansiyeli açısından SWOT analizi

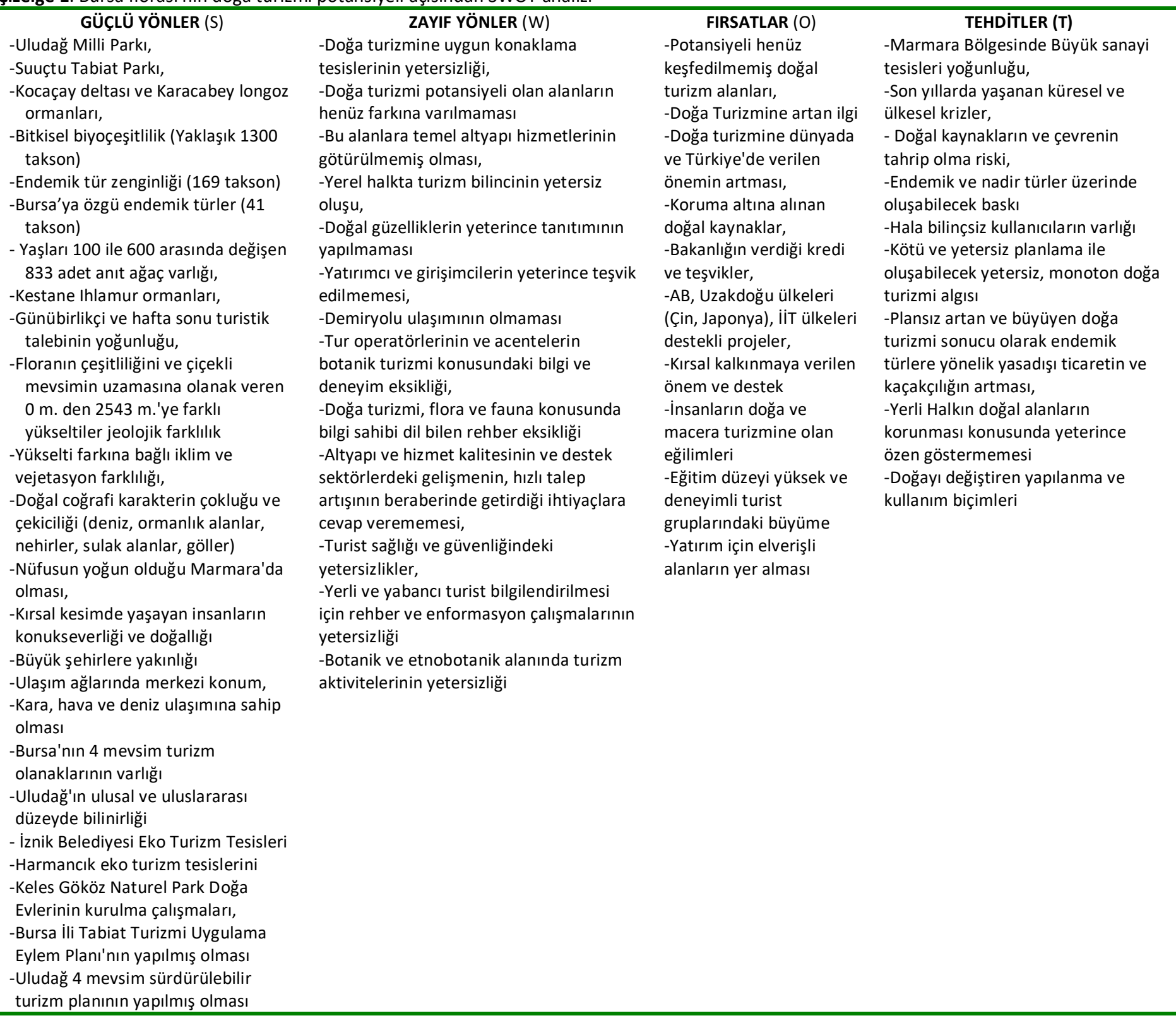




\section{SONUÇLAR VE ÖNERILER}

Swot analizi ve doğa turizmine uygun alanlar ile ilgili elde edilen bulgulara göre aşağıdaki sonuçlara varılmıştır.

- Bursa'nın doğa turizmine bağlı ekoturizm aktivitelerinin başarıya ulaşabilmesi açısından en güçlü yönü floranın zengin olmasıdır.

- Kampçılık ve yayla turizmi, piknikçilik, doğa yürüyüşü, doğa ve bitki fotoğrafçılığı, botanik turları, doğa ve macera oyunları, yenilebilir, içilebilir ve şifalı bitki (Etnobotanik) turları, anıt ağaç turları ve longoz ormanı turları Bursa florasının sahip olduğu kaynaklara bağıı olarak ortaya çıkan doğa turizmi faaliyetleridir.

- Piknikçilik faaliyetleri Bursa'nın farklı bölgelerindeki alanlara dağıtılarak hem Uludağ'daki kapasiteyi çok aşan kullanım engellenmeli hem de ilin farklı bölgelerinin de kalkınmasına katkı sağlanmalıdır.

- Doğa turizmi geniş alanlarda birbiriyle bağlantılı çok sayıda aktiviteyi kapsayacak şekilde planlandığında katılımcılar üzerinde çok daha fazla etki bırakan ve getirisi daha fazla olan bir turizm koludur. Bursa doğa turizmi kaynakları açısından bölgelere ayrılmalı, bu bölgelerde bulunan küçük kapasiteli ve kısa süre kullanımlı kaynaklar birbiriyle ilişkilendirilerek ulusal ve uluslararası düzeyde destinasyonlar haline dönüştürülmelidir.

- Seçilen alanlarda güzergâh üzerinde yer alan mağara, şelale, anıt ağaç, kaya oluşumu, sportif alanlar, iniş ve çıkış rampası tırmanma alanları, kamping alanları, manzara, gözlem ve fotoğraf alanları, endemik bitki noktaları, yenilebilir doğal meyve ve sebze toplama noktaları, eğer mevcutsa doğal sit, tabiat parkı ve tarihi alan ziyaret noktaları için bilgilendirme noktaları, güvenlik tedbirleri ve gerekli altyapılar tamamlanmalıdır.

- Yüksek rakımlı noktalarda oluşturulacak seyir ve gözlem noktalarında güneşin doğuşu, batışı, manzara ve bitki fotoğraflamak amaçlı konseptler oluşturulmalıdır.

- Botanik turizmi kaynaklarının özellikle de endemik türlerin sürdürülebilir kullanımının sağlanması gerekmektedir. $\mathrm{Bu}$ çalışmalara koruma ve sürdürülebilirlik için tedbirler alınarak başlanmalıdır. Bu tedbirlerden biri endemik türlerin doğal popülasyonlarının koruma altına alınmasıdır.
Biyokaçakçılığa zemin hazırlanmaması, endemiklerin doğal popülasyonları üzerinde baskı oluşturulmaması ve mevcut baskının yok edilmesi için bu zorunludur.

- Bitki sayısı açısından yetersiz olan nadir endemik türlerin varlıklarının sürdürülmesi için bu türlerin mevcut varlıklarının korunması yanında alanları dışında üretilerek koruma altına alınmaları ve bu türlerin doğal popülasyonları dışında oluşturulacak alanlarda kullanıma sunulmaları gerekmektedir. Endemik bitkilerin popülasyonlarından bir sefere mahsus toplanacak tohumlardan kültür koşullarında üretim yapılmalı, üretilen bireylerle, belirlenecek doğal ortamlarda Bursa Endemik Bitkileri Botanik Bahçesi oluşturulmalıdır. Bundan sonraki Bursa endemik bitkileri ile ilgili tüm çalışmalar bu bahçelerdeki bitkilerden üretilecek bireyler üzerinde yapılmalıdır. Bu bahçelerde hem botanik turizmi hem de Ex-situ muhafaza alanı olarak değerlendirilmelidir. Bu bahçeler oluşturulurken hem bitkilere doğala yakın habitatlar oluşturmak hem de ziyaretçilere macera, doğallık, keşif, görsel güzellik, seyir duyguları yaşatacak şekilde oluşturulmalıdır. Bu alanın tüm yıl cazip hale gelebilmesi için, tanıtım ve bilgilendirme amaçlı, resimli tabela, broşür, bilgi notları ile türlerin dinlenme dönemlerinde de ziyaretçilerin ilgisini çekecek şekilde desteklenmeli, tüm yıl çiçekli bitki bulundurmak için endemikler dışında doğal bitkiler ve özellikle tıbbi ve aromatik amaçlı kullanılan bitkiler ve faklı sezonlarda çiçekli bitkilerle desteklenmelidir.

- Bu bahçelerin devamlılıklarının sağlanması için buradaki bitkilerin oluşturduğu tohumların bir kısmı sürekli toplanarak üretim ve popülasyonlardaki bitki sayılarının devamlıı̆ını sağlamak amaçlı kullanıııken, bir kısmı da bitki üzerinde bırakılarak, doğal tohum dağılımı ve türlerin yeni habitatlarında doğal olarak popülasyon oluşturmalarına ortam sağlanmalıdır.

- Özellikle akarsuların bulunduğu, ormanlık, kayalık alanlarda oluşturulacak macera oyunları parkurlarına, su faktörüne bağlı faaliyetlerinde eklenmesi ile daha eğlenceli hale getirilerek, heyecan düzeyi yüksek parkurlara dönüştürülmelidir.

- Doğal yürüyüş parkurlarının başlama istasyonlarında yapılacak bilgilendirme sonrasında mevsime uygun yenilebilir, içilebilir ve şifalı bitkilerin kontrollü şekilde 
toplanması amacıyla yapılacak turlar diğer doğa aktiviteleri ile birleştirilerek sunulduğunda ya da doğa yürüyüşü turlarına şifalı bitki, doğal meyve ve sebze toplama aktiviteleri eklendiğinde doğa turizmi faaliyetlerinin çeşitlendirilip eğlenceli ve çekici hale getirilmesi mümkündür. Bu faaliyetler için bu konularda uzman, bu bitkileri iyi bilen rehberler yetiştirilmelidir.

- Doğa turizmi faaliyetlerin organize edildiği bölgelerde yerel halka tahsis edilecek doğal ürün satış noktaları, doğa turizmi felsefinin gereklerinin yerine getirilmesi, halkın faaliyetlerin içine çekilmesi ve halkın bu faaliyetlerden faydalandırılarak gelir düzeyinin yükseltilmesine de katkı sağlanmalıdır.

- Yüksek değerlere sahip doğal ekolojik sahalar her zaman yüksek turizm potansiyeli içermeyebilirler. Bu nedenle yatırımlardan önce bu faaliyetler ve kaynak alanları ile ilgili arz ve talebin ortaya konulması, ekonomik, ekolojik ve sürdürülebilirlik açısından uygun ve yatırım yapılabilir bulunan konuların gündeme alınması gerekmektedir (Anonim 2011).

- Doğa turizmi ve ekoturizm alanlarında genel bir sorun alt yapı ve üst yapı çalışmalarının yetersiz olduğu ve ekoturizmin gelişmesinin önündeki en büyük tehdidin güvenlik sorunu olduğu, turistlerin ve yerel halkın sürdürülebilirlik anlayışını kavrayamamasından dolayı uzun vadede alanların tehdit altında olduğu saptanmıştır. Doğa turizmi için kullanılacak alanlarda, çeşme, wc, barınak, mesafe ve yön levhaları tamamlanmalı, dağ yürüyüşü rotalarının Küresel Yer Belirleme Sistemi (GPS) ile uydulara tanıtımalı, doğa turizmi alanlarında iletişim ağları kesintisiz çalışacak şekilde yaygınlaştırımalı, alanların doğallığını bozacak yeni ulaşım ağlarından kaçınılmalıdır (Akın 2016; Kaypak 2010).

- Doğa turizminin taşıdığı en büyük risk doğal alanların bilinçsiz ve aşırı kullanımı ile kısa sürede tüketilmesidir. Bunun önlenmesi için planlamalarda kapasiteye dikkat edilmeli, turizm faaliyetleri mümkün olduğunca geniş alanlara yayılarak belli bölgelerin aşırı kullanımı engellenmeli, kullanılan alanların yenilenmesi, bakımı ve korunması için mutlaka kaynak ayrımalıdır. Turizm faaliyetlerine katılanlar ve bu konuda çalışanların sürdürülebilirlik ve koruma kültürü konusunda bilinçlendirilmesi yapılmalıdır.
- Ülkemizdeki doğa ve macera turlarına yabancı turist katılımının az olduğu görülmektedir. Bunun nedeni, bu konuda yurtdışında yeterince tanıtım yapılmamasıdır. Daha çok iç pazara hitap eden doğa turizminde dış tanıtımlara ağırlık verilmelidir. Araştırmalar göstermektedir ki, tüketici zihninde marka ve ürünle ilgili oluşan olumlu duygular, o mal veya ürünün satın alınmasında etkilidir. Markalaşmış ürünlerin tercih edilmesinde ve satın alınmasında pozitif duyguların önemli ölçüde etkisi vardır (Veen and Song 2014). Bu nedenle Bursa için Doğa Turizmi Planlama Tanıtım ve Koordinasyon Merkezi oluşturulmalıdır. Bu merkezde Bursa genelinde doğa turizm alanlarının sürdürülebilir kullanıma açılması, kullanımın planlanması, tanıtımı ve satışı yapılmalıdır. Alan ve faaliyetlerle ilgili materyal hazırlama ve basımları yapılmalıdır. Turistler alanı gezerken gördükleri objeler hakkında basılı ve dijital ortamda bilgi metinleri bulabilmelidir. Bu merkezde doğa turizmi rehberlerinin yetiştirilmesi, eğitimi, yetkilendirilmeleri de yapılmalıdır (Akkiprik 2011). Kısacası Bursa'nın Entegre Doğal Alan Yönetimi'ni sağlayacak bir merkez olmalıdır ve markalaşmaya gidilmelidir.

- Bursa'nın Doğal kaynaklarının ekonomik değerlere dönüştürülebilmesi için 2016 yılında hazırlanan "Bursa Ili Tabiat Turizmi Uygulama Eylem Planı 2016-2019" ve "Uludağ 4 Mevsim Sürdürülebilir Turizm Planı'nın hayata geçirilmesi hızlandırılmalı, önümüzdeki yıllarda hazırlanacak yeni planlar ya da revizyonlarda bu çalışmada belirlenen floraya bağı doğa turizmi faaliyetleri de planlara eklenmelidir.

Not: Bu çalışma 4. Uluslararası Odundışı Orman Ürünleri Sempozyumu'nda bildiri olarak sunulmuş ve özeti bildiri özetleri kitabında basılmıştır.

\section{KAYNAKLAR}

Akın A (2016) Ekoturizm Alanlarının Değerlendirilmesi ve Ekoturizmin Uygulanabilirliğinin Araştırılması (Gaziantep Örneği), Uluslararası Sosyal ve Ekonomik Bilimler Dergisi (IJSES), 6 (2): 25-31

Akkiprik A (2011) Hatay illi Samandağ îlçesi Ekoturizm Kullanımına Yönelik Peyzaj Potansiyelinin Saptanması", Selçuk Üniversitesi Fen Bilimleri Enstitüsü, Peyzaj Mimarlığı ABD, Yüksek Lisans Tezi. Hatay Ankaya FÜ, Yazıcı K, Balık G, Aslan B G (2018) Dünyada ve Türkiye'de Ekoturizm, Sosyal-Kültürel ve Ekonomik Katkıları, Ulusal Çevre Bilimleri Araştırma Dergisi, Sayı 1(2): 69-72 
Anonim (2011) Kayseri Doğa Turizmi Master Planı, 2013 - 2023, Orman ve Su İşleri Bakanlığı, Doğa Koruma ve Milli Parklar Genel Müdürlüğü, Kayseri

Anonim 2012. Ekoturizm Sektör Raporu, Batı Akdeniz Kalkınma Ajansı $42 \mathrm{~s}$.

Anonim (2015) Bursa ilii Tabiat Turizmi Uygulama Eylem Planı 20162019, T.C. Orman ve Su İşleri Bakanlığı, Doğa Koruma ve Milli Parklar 2. Bölge Müdürlüğü, Bursa

Anonim (2015b) Macera ve Doğa Turizmi için 400 milyar dolar harcanıyor, Turizm \& Yatıım İşletme ve Endüstri dergisi, sayı 37, İstanbul

Anonim (2016) Uludağ 4 Mevsim Sürdürülebilir Turizm Planı Nihai Raporu. Bursa Eskişehir, Bilecik Kalkınma Ajansı, ATC Consultans $\mathrm{GmbH}$

Anonim (2012) Bursa Doğa Turizmi Eylem Planı 2013-2017, Bursa

Bremness L (1999) Şifalı Otlar - Cep Ansiklopedisi, (Çeviri; Nejat Ebcioğlu), İnkılap Kitabevi, 240 s. İstanbul

Cinnioğlu H (2016) Sürdürülebilir Ekonomik Kalkınma Kapsamında Ekoturizmin Çevre Üzerindeki etkilerinin Eleştirel Bir Bakış Açısıyla İncelenmesi, Namık Kemal Üniversitesi Sosyal Bilimler Enstitüsü, Sosyal Bilimler Metinleri, No: 03 / 2015 online; http://sosyalbe.nku.edu.tr/ (Erişim Tarihi:08.03.2019)

Daşkın R, Kaynak G (2010) Vascular Flora of the Uludag Mt (Bursa, Turkey) I", Phytologia Balcanica. 16/3: 369-383

Daşkın R, Kaynak G (2010b) Vascular Flora of the Uludag Mt (Bursa, Turkey) II", Phytologia Balcanica. 16/3: 385-411

Düzgüneş E, Demirel Ö (2013) Maçka Bölgesi'nin Alternatif Turizm Potansiyeli Açısından Değerlendirilmesi, İnönü Üniversitesi Sanat ve Tasarım Dergisi, 3 (7), 1-11

Erdoğan N (2003) Çevre ve Ekoturizm, Ankara: Erk Yayınları, s.68,

Erken K, Kaya E, Özhatay N, Şener B, Uysal E, Arslan N, Uçkun Z, Ellialtıoğlu Ş, Hantaş C, Erkal S, Atak A, Fidancı A (2009) Bazı Doğal Bitkilerin Kültüre Alınması, Yeni Tür ve Çeşitlerin Süs Bitkileri Sektörüne Kazandırılması (TÜBiTAK-KAMAG 1007-105G068) İş Paketi 3: Türkiye'de Yetişen İris Türlerinin Taranması, Seleksiyonu, Yetiştirme Tekniklerinin Belirlenmesi ve Süs Bitkileri Sektörüne Kazandırılması Projesi (2006-2009)

Erken K, Özzambak M E (2011) Katırtırnağı (Spartium junceum (L.), Manisa Katırtırnağı (Genista lydia var. lydia Boiss) ve Sarızeybek Çalısı (Chamaecytiscus hirsutus (L.), link) Taksonlarının Çoğaltım Yöntemleri ve Süs Bitkisi Özelliklerinin Saptanması Projesi (20082011)

Güleryüz G (2000) Uludağ Alpin Çiçekleri (Alpine Flowers of Uludağ), Bursa Valiliği il Turizm Müdürlüğü, Bursa

Gürsoy Y (2015) Giresun'da Yürüyüş Turizminin Çeşitlendirilmesi, Uluslararası Sosyal Araştırmalar Dergisi Cilt: 8 Sayı: 37 Volume: 8 Nisan 2015 www.sosyalarastirmalar.com ISSN: 1307-9581
Kaptan Ö (2018) Bursa'nın çınarları, (Online) https://sehirmedya.com/aktuel/kultur-sanat/bursanin-cinarlari (son erişim tarihi 25.09.2018)

Karaca O B, Yıldırım O, Çakıcı C (2015) Gastronomi Turizminde Otlar, Ot Yemekleri ve Sağlıkla İlişkisi Üzerine Bir Değerlendirme, Journal of Tourism and Gastronomy Studies 3/3 27-42

Karamanoğlu K Öder Ö (1973) Bursa İli ve Çevresinde Yetişen Bazı Şapkalı Mantarlar Ankara Ecz. Fak. Mec. Ankara 3, 13

Kaya E, Özhatay N, Akalın E,. Kültür Ş, Güler N, Koyuncu M, Arslan N, Erken K, Erken S, Gülbağ F, Uysal E, Hantaş C, Polat Z, (2014) Türkiye Geofitlerinin Kültüre Alınması Yeni Tür Ve Çeşitlerin Illgili Sektörlere Kazandırılması (1007 TÜBiTAK KAMAG 110G007 Nolu Proje) 2.1 Alt İş Paketi; Batı Anadolu ve Doğu Karadeniz Bölgelerinde Mevcut Geofit Bitki Türlerinin Koleksiyonu projesi (2010-2014)

Kaypak Ş (2010) Ekolojik Turizmin Sürdürülebilirliği, Alanya İşletme Fakültesi Dergisi, Alanya

Kaypak Ş (2012) Ekolojik Turizm ve Sürdürülebilir Kırsal Kalkınma, KMÜ Sosyal ve Ekonomik Araştırmalar Dergisi, 14 (22): 11-29,

Külekçi E A, Bulut Y (2016) Oltu ve Olur İlçelerinde Peyzaj Değeri Taşıyan Bazı Yerörtücü Bitkilerin Flora Turizmi Potansiyeli Açısından Değerlendirilmesi Iğdır Üniversitesi Fen Bilimleri Enstitüsü Dergisi 6(1): 95-105

Malyer H, Daşkın R, Bahçıvan G (2016) Flora ve Vegetasyon, Şu eserde; Sadağı Kanyonu tabiat parkı Biyolojik Çeşitlilik Burçak Gönül, Edit., T.C. Orman ve Su İşleri Bakanlığı yayını, Bursa

Oktay K, İşlek i, Yaşar U (2016). Kastamonu'da Doğa Turizmi Potansiyelinin Değerlendirilmesi, Türk Bilimsel Derlemeler Dergisi 9 (2): 47-54

Özhatay N, Byfield A, Atay S (2005) Türkiye'nin 122 Önemli Bitki Alanı, WWF Türkiye, 2005, ISBN: 9759243377, 9789759243371

Sayan Atanur G, Özer M N (2008) Dünyadan bir turizm politikası örneği ve Türkiye için öneriler, Ulusal Turizm Politikaları ve Mimarlık Sempozyumu, 31 Ekim-01 Kasım Antalya

Şahinbaş i (2016) Doğa Bursa (Doğal ve Kültürel Rotalar), Bursa Valiliği, Bursa

Tuncer M, Çavuş S (2017) Gelişen Turizm Destinasyonlarından Biri Olarak Aksaray İlinin Alternatif Turizm Potansiyelinin Belirlenmesine Yönelik Bir Araştırma. Erzincan Üniversitesi Sosyal Bilimler Enstitüsü Dergisi (ERZSOSDE) ÖS-IV: 51-60

Veen RV, Song H (2014) Impact of The Perceived Image of Celebrity Endorsers on Tourists Intentions to Visit, Journal of Travel Research, 53 (2), 211-224

Yılmaz H, Karahan F (2003) Eko Turizm Yaklaşımlarında Flora Turizmi Palandöken Dağlarının Potansiyeli Türkiye I. Ulusal Erciyes Sempozyumu 23-25 Ekim 2003 Erciyes-Kayseri 